\title{
Oxidative Coupling of Aromatic Substrates with Alkynes and Alkenes under Rhodium Catalysis
}

\author{
Tetsuya Satoh and Masahiro Miura
}

\begin{tabular}{|c|l|}
\hline Citation & Chemistry - A European Journal, 16(37); 11212-11222 \\
\hline Issue Date & $2010-10-4$ \\
\hline Type & Journal Article \\
\hline Textversion & $\begin{array}{l}\text { This is the peer-reviewed version of the following article: Satoh, T. and Miura, M. } \\
\text { (2010), Oxidative Coupling of Aromatic Substrates with Alkynes and Alkenes under } \\
\text { Rhodium Catalysis. Chem. Eur. J., 16: 11212-11222., which has been published in } \\
\text { final form at https://doi.org/10.1002/chem.201001363. This article may be used for } \\
\text { non-commercial purposes in accordance with Wiley-VCH Terms and Conditions for } \\
\text { Self-Archiving. }\end{array}$ \\
\hline DOI & $\begin{array}{l}\text { This is the accepted manuscript version. Please cite only the published version. } \\
\text { 10.1002/chem.201001363 }\end{array}$ \\
\hline
\end{tabular}

Self-Archiving by Author(s)

Placed on: Osaka City University Repository

Satoh, T. and Miura, M. (2010), Oxidative Coupling of Aromatic Substrates with Alkynes and Alkenes under Rhodium Catalysis. Chemistry - A European Journal., 16: 11212-11222. Doi:10.1002/chem.201001363 


\title{
Oxidative Coupling of Aromatic Substrates with Alkynes and Alkenes under Rhodium Catalysis
}

\author{
Tetsuya Satoh*[a] and Masahiro Miura*[a]
}

\author{
Department of Applied Chemistry, Faculty of Engineering, Osaka University, Suita, Osaka 565-0871, Japan
}

Fax: (+81) 6-6879-7361, E-mail: satoh@chem.eng.osaka-u.ac.jp; miura@chem.eng.osaka-u.ac.jp

\begin{abstract}
Aromatic substrates bearing oxygen- and nitrogen-containing substituents undergo oxidative coupling with alkynes and alkenes under rhodium catalysis via regioselective $\mathrm{C}-\mathrm{H}$ bond cleavage. Coordination of the substituents to the rhodium center is the key to activate the $\mathrm{C}-\mathrm{H}$ bonds effectively. Various fused-ring systems can be constructed through these reactions.
\end{abstract}

Keywords: C-H activation - fused-ring systems • homogeneous catalysis $\bullet$ oxidative coupling $\bullet$ rhodium

\section{Introduction}

The transition-metal-catalyzed organic reactions via $\mathrm{C}-\mathrm{H}$ bond cleavage have attracted much attention from the atom- and stepeconomical points of view, and a variety of catalytic processes through different modes for activating the ubiquitously available bond have been developed. ${ }^{[1]}$ Among the most promising activation strategies is to utilize the proximate effect by coordination of a functional group in a given substrate to the metal center of a catalyst that leads to regioselective $\mathrm{C}-\mathrm{H}$ bond activation and functionalization. As the pioneering work in this area, Murai and coworkers reported the ruthenium-catalyzed coupling of aromatic ketones with alkenes involving regioselective $\mathrm{C}-\mathrm{H}$ activation at the ortho-position. ${ }^{[2]}$ Then, the coupling of various aromatic substrates bearing heteroatom containing functional groups with alkenes and alkynes have been developed.

The oxidative coupling reactions of these substrates, on the other hand, are highly useful as synthetic methods for $\pi$ conjugated molecules. In 1981, Horino and Inoue disclosed the stoichiometric ortho-vinylation of acetanilides with alkenes in the presence of $\mathrm{Pd}(\mathrm{OAc})_{2} \cdot{ }^{[3]}$ After 15 year hiatus, the early examples of the catalytic version involving a $\mathrm{Pd}^{\mathrm{II}} / \mathrm{Pd}^{0}$ cycle were reported (Scheme 1) ${ }^{[4]}$ Thus, we succeeded in conducting the palladiumcatalyzed oxidative coupling of 2-phenylphenols, ${ }^{\text {[4a] }} \mathrm{N}$-sulfonyl-2phenylanilines, ${ }^{[4 b]}$ and benzoic acids ${ }^{[4 b]}$ with alkenes by using $\mathrm{Cu}(\mathrm{OAc})_{2}$ and air as cocatalyst and terminal oxidant, respectively. The catalytic ortho-vinylation of acetoanilides was also reported by de Vries and coworkers. ${ }^{[4 c]}$ In this reaction, 1,4-benzoquinone and $p$-toluenesulfonic acid were employed as oxidant and promoter, respectively. Later, the reactions of benzylamines ${ }^{[5]}$ and pyridine $N$-oxides ${ }^{[6]}$ have been developed. In spite of such evolution, the scope of substrates for the oxidative coupling is still limited. Furthermore, high palladium loadings and/or acid- and metal salt additives are usually required for realizing practical reaction efficiency. Without such elaboration, the homogeneous palladium-based catalysts tend to decompose into inactive bulk metal. ${ }^{[7]}$

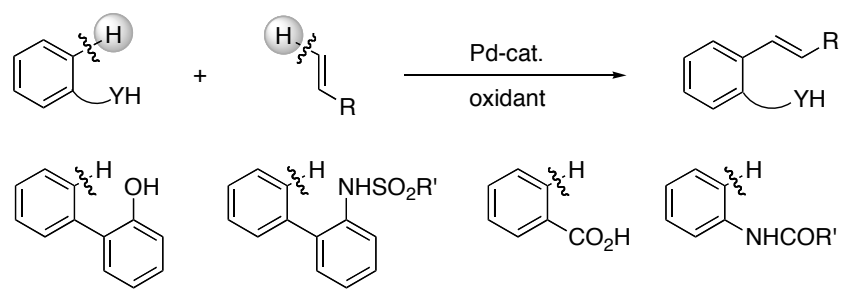

Scheme 1. Early examples for Pd-catalyzed oxidative coupling via regioselective $\mathrm{C}-\mathrm{H}$ bond cleavage.

On the other hand, the $\mathrm{Rh}^{\mathrm{III}} / \mathrm{Rh}^{\mathrm{I}}$ process, as well as $\mathrm{Pd}^{\mathrm{II}} / \mathrm{Pd}^{0}$, is also known to be applicable to organic oxidation reactions. ${ }^{[1,8]}$ Around 40 years ago, the rhodium-catalyzed oxidation of olefins was extensively investigated ${ }^{[9]}$ in addition to a well-known palladium-catalyzed version, i. e. Wacker-process. Since then, the rhodium catalyst systems for oxidation have been less explored than those with palladium. In 2000, Matsumoto and Yoshida reported an example for the oxidative coupling of benzene with ethylene under rhodium catalysis. ${ }^{[10]}$ The reactions of other substrates were not examined. For the last four years, however, the rhodium-catalyzed oxidative couplings of various aromatic substrates with alkynes and alkenes have been extensively investigated (Scheme 2). Basically, the turnover numbers of the rhodium catalysts in such reactions are much higher than those of palladium. In this account, these selective coupling reactions are summarized by the identity of substrate categories.

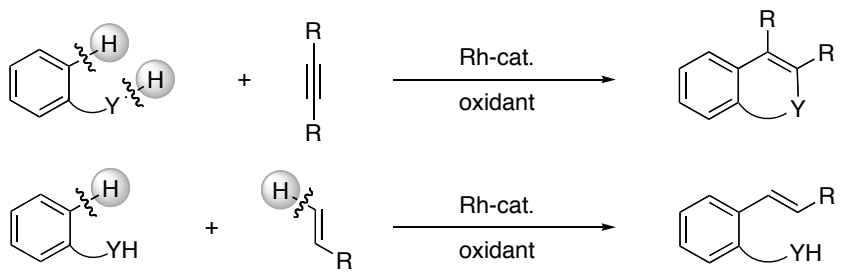


Scheme 2. Rh-Catalyzed oxidative coupling of aromatic substrates with alkynes and alkenes via regioselective $\mathrm{C}-\mathrm{H}$ bond cleavage.

\section{Coupling of Carboxylic Acids}

A carboxyl function is known to act as a unique, removable directing group. A number of palladium-catalyzed arylation reactions at the ortho- and ipso-positions of the key function have been reported. ${ }^{[1 \mathrm{~b}, \mathrm{c}, 11]}$ The oxidative vinylation around the function principally using palladium catalysts has also been developed. ${ }^{[4 b, 12]}$ Although it has been shown by Maitlis and coworkers that the carboxyl group can act as a good anchor for the stoichiometric cyclometalation on rhodium complexes, ${ }^{[13]}$ catalytic reactions involving such a step have been scarcely explored.

In 2007, we reported the rhodium-catalyzed oxidative coupling of benzoic acids with internal alkynes (Scheme 3). ${ }^{[14]}$ Thus, treatment of benzoic acid with 1.2 equivalents of diphenylacetylene using $0.5 \mathrm{~mol} \%$ of $\left[\mathrm{Cp}^{*} \mathrm{RhCl}_{2}\right]_{2}$ and 2 equivalents of $\mathrm{Cu}(\mathrm{OAc})_{2} \cdot \mathrm{H}_{2} \mathrm{O}$ in $o$-xylene under $\mathrm{N}_{2}$ affords a $1: 1$ coupling product, 3,4-diphenylisocoumarin in $90 \%$ yield $\left(\mathrm{Cp}^{*}=\right.$ $\eta^{5}$-pentamethylcyclopentadienyl), along with a small amount of 1,2,3,4-tetraphenylnaphthalene $(3 \%)$. None or trace amounts of the coupling products can be obtained in the case using $\mathrm{RhCl}_{3} \cdot \mathrm{H}_{2} \mathrm{O}, \mathrm{Rh}(\mathrm{acac})_{3},[\mathrm{RhCl}(\mathrm{cod})]_{2}$, or $\left[\mathrm{RhCl}\left(\mathrm{C}_{2} \mathrm{H}_{4}\right)_{2}\right]_{2}$ in place of $\left[\mathrm{Cp}^{*} \mathrm{RhCl}_{2}\right]_{2}(\mathrm{acac}=$ acetylacetonate, $\operatorname{cod}=$ cyclooctadiene $)$. Under the conditions using $\left[\mathrm{Cp} * \mathrm{RhCl}_{2}\right]_{2}$ as the catalyst, dialkylacetylenes such as 4-octyne and 8-hexadecyne also undergo the coupling with benzoic acid smoothly to produce the corresponding 3,4-dialkylisocoumarins in good yields. The reactions of unsymmetrical alkylphenylacetylenes give 4-alkyl-3phenylisocoumarins predominantly.
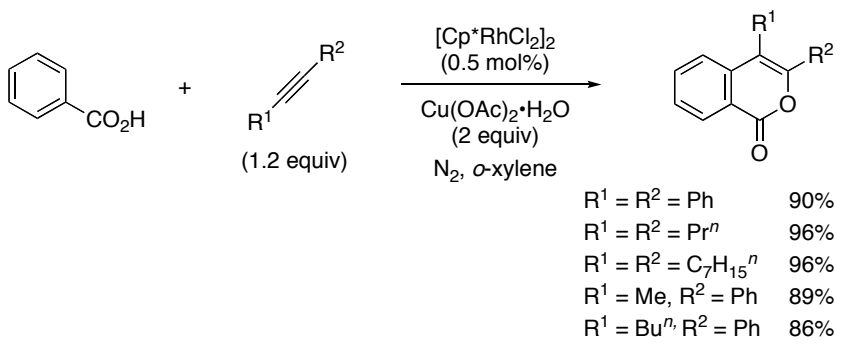

Scheme 3. 1:1 Coupling of benzoic acid with alkynes.

From the reactions of $p$-, $m$-, and $o$-substituted benzoic acids with diphenylacetylene, the corresponding isocoumarins can be obtained (Scheme 4). The reaction using 1-naphthoic acid in place of benzoic acids needs refluxing the solvent for the efficient coupling.

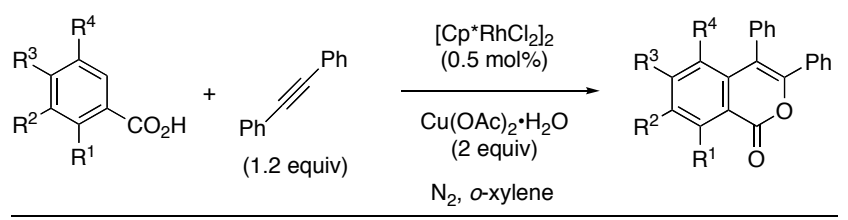<smiles>O=c1oc(-c2ccccc2)c(-c2ccccc2)c2ccccc12</smiles>

$\mathrm{R}^{3}=\mathrm{Me}, 92 \%$

$\mathrm{R}^{3}=\mathrm{OH}, 63 \%$

$\mathrm{R}^{3}=\mathrm{Cl}, 82 \%$

$\mathrm{R}^{3}=\mathrm{CF}_{3}, 73 \%$<smiles>Cc1ccc2c(-c3ccccc3)c(-c3ccccc3)oc(=O)c2c1</smiles>

$97 \%$<smiles>Cc1cccc2c(-c3ccccc3)c(-c3ccccc3)oc(=O)c12</smiles>

$67 \%$<smiles>COc1cc(OC)c2c(-c3ccccc3)c(-c3ccccc3)oc(=O)c2c1</smiles>

$99 \%$<smiles>O=c1oc(-c2ccccc2)c(-c2ccccc2)c2ccc3ccccc3c12</smiles>

$3 \%$
Scheme 4. 1:1 Coupling of benzoic acids with diphenylacetylene.

A plausible mechanism for the oxidative coupling is illustrated in Scheme 5, in which neutral ligands are omitted for clarity. Coordination of the carboxylate oxygen to $\mathrm{Cp}^{*} \mathrm{Rh}^{\mathrm{III}} \mathrm{X}_{2}$ species gives an $\mathrm{Rh}^{\mathrm{III}}$ benzoate $\mathbf{A}$. Subsequent cyclorhodation to form a rhodacycle intermediate $\mathbf{B},{ }^{[13]}$ alkyne insertion, and reductive elimination occur to produce an isocoumarin. The resulting $\mathrm{Cp}^{*} \mathrm{Rh}^{\mathrm{I}}$ species may be oxidized in the presence of a $\mathrm{Cu}^{\mathrm{II}}$ salt to regenerate $C p * R h^{\text {III }} X_{2}$. The minor product, 1,2,3,4-tetrasubstituted naphthalenes, may be yielded via decarboxylation of $\mathbf{C}$ to form $\mathbf{D}$, the second alkyne insertion, and reductive elimination.

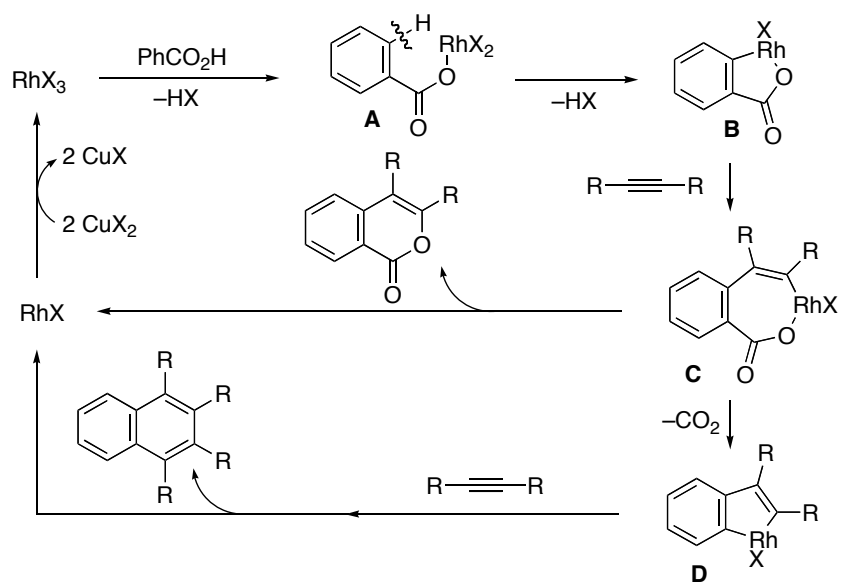

Scheme 5. A plausible mechanism for the coupling of benzoic acid with alkynes.

From same substrates, benzoic acids and alkynes, 1,2,3,4tetrasubstituted naphthalenes can be exclusively produced by using $\left[\mathrm{Cp}^{*} \mathrm{IrCl}_{2}\right]_{2}$ and $\mathrm{Ag}_{2} \mathrm{CO}_{3}$ as catalyst and oxidant, respectively (Scheme 6). 

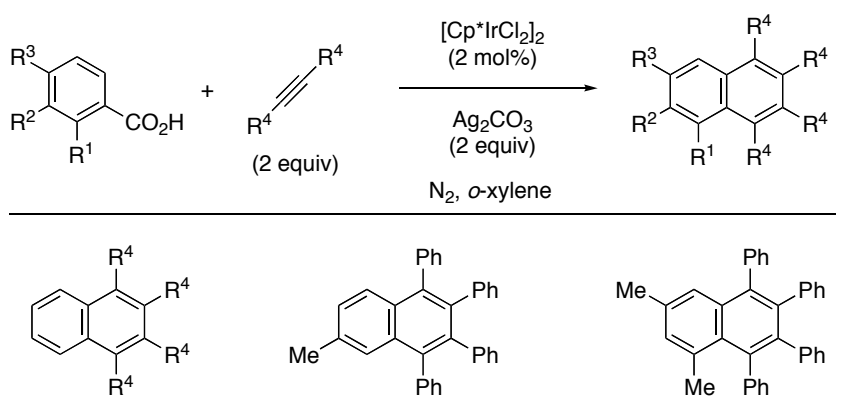<smiles>Cc1ccc2c(-c3ccccc3)c(-c3ccccc3)c(-c3ccccc3)c(-c3ccccc3)c2c1</smiles><smiles>Cc1cc(C)c2c(-c3ccccc3)c(-c3ccccc3)c(-c3ccccc3)c(-c3ccccc3)c2c1</smiles>

$\mathrm{R}^{4}=\mathrm{Ph}, 88 \%$

$95 \%$

$93 \%$

$\mathrm{R}^{4}=4-\mathrm{MeOC}_{6} \mathrm{H}_{4}, 64 \%$

$\mathrm{R}^{4}=4-\mathrm{ClC}_{6} \mathrm{H}_{4}, 91 \%$

Scheme 6. 1:2 Coupling of benzoic acids with alkynes.

Besides benzoic- and naphthoic acids, heteroarene carboxylic acids and aromatic diacids also undergo the oxidative coupling in DMF with diphenylacetylene and 4-octyne, respectively. ${ }^{[15]}$ As shown in Schemes 7 and 8, complicated bi- and tricyclic systems can be constructed effectively through the process. In the reactions of diacids, the use of $\mathrm{Ag}_{2} \mathrm{CO}_{3}$ as oxidant is essential. With $\mathrm{Cu}(\mathrm{OAc})_{2} \cdot \mathrm{H}_{2} \mathrm{O}$, no desired products are obtained.
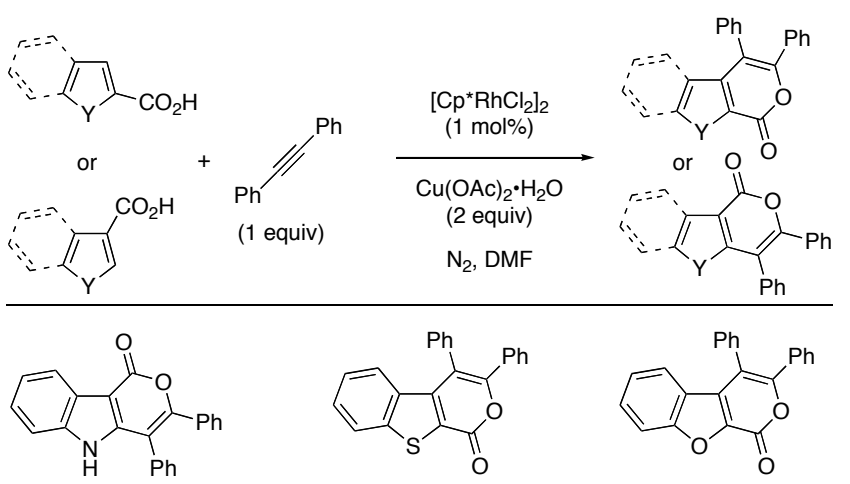

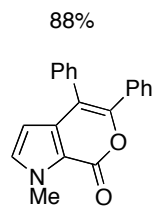

$87 \%$

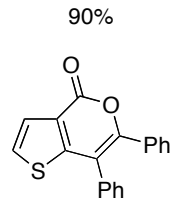

$71 \%$

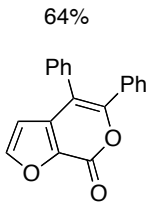

$43 \%$
Scheme 7. 1:1 Coupling of heteroarene carboxylic acids with diphenylacetylene.

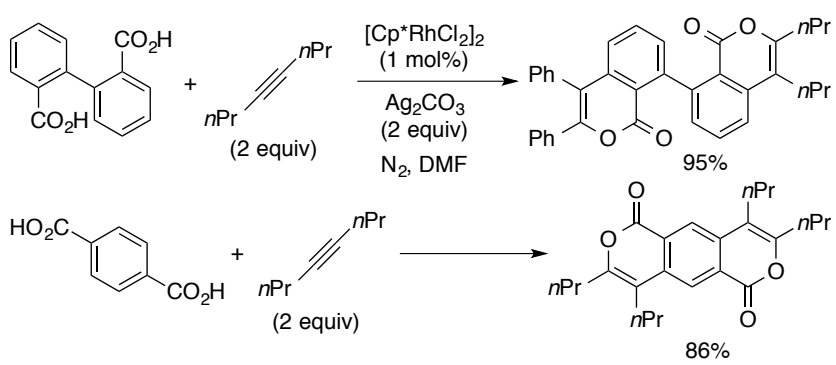

Scheme 8. 1:2 Coupling of aromatic diacids with 4-octyne.

Interestingly, the reaction of benzoic acids with alkynes takes place efficiently even with a reduced amount (5 mol\%) of $\mathrm{Cu}(\mathrm{OAc})_{2} \bullet \mathrm{H}_{2} \mathrm{O}$ under air. ${ }^{[14]}$ Thus, the aerobic oxidative coupling using a catalyst system of $\left[\mathrm{Cp} * \mathrm{RhCl}_{2}\right]_{2} / \mathrm{Cu}(\mathrm{OAc})_{2} \cdot \mathrm{H}_{2} \mathrm{O}$ proceeds in DMF to afford the corresponding isocoumarins in good to excellent yields (Scheme 9). In particular, anthranilic- and salicylic acid derivatives smoothly undergo the reaction to produce 8 -amino- and 8 -hydroxyisocoumarins, ${ }^{[15]}$ which are known to exhibit a broad range of interesting biological and photochemical properties. ${ }^{[16]}$

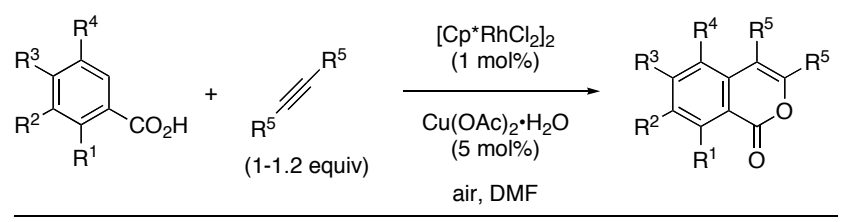

$$
\text { (1) }
$$

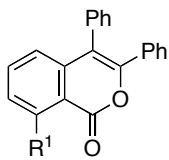

Scheme 9. 1:1 Aerobic oxidative coupling of benzoic acids with diphenylacetylene.

$N$-Phenylanthranilic acid also reacts with diarylacetylenes under the aerobic conditions in $o$-xylene to form the corresponding 8-( $N$-phenylamino)isocoumarins in good yields (Scheme 10). However, the use of a different rhodium catalyst system, $\quad[\mathrm{RhCl}(\mathrm{cod})]_{2} / \mathrm{C}_{5} \mathrm{H}_{2} \mathrm{Ph}_{4}, \quad$ in place of $\left[\mathrm{Cp} * \mathrm{RhCl}_{2}\right]_{2}$ dramatically changes the reaction pathway $\left(\mathrm{C}_{5} \mathrm{H}_{2} \mathrm{Ph}_{4}=1,2,3,4\right.$ tetraphenyl-1,3-cyclopentadiene). Thus, the reaction with this catalyst in DMF proceeds through double $\mathrm{C}-\mathrm{H}$ bond cleavage and decarboxylation to afford 4-(1,2-diarylethenyl)-9H-carbazoles.

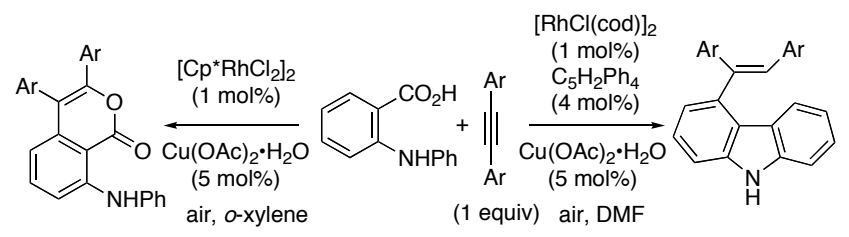

$\mathrm{Ar}=\mathrm{Ph}, 94 \%$

$\mathrm{Ar}=4-\mathrm{MeC}_{6} \mathrm{H}_{4}, 89 \%$

$\mathrm{Ar}=4-\mathrm{MeOC}_{6} \mathrm{H}_{4}, 91 \%$

$\mathrm{Ar}=4-\mathrm{ClC}_{6} \mathrm{H}_{4}, 77 \%$

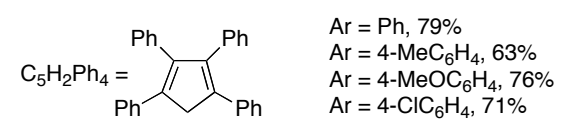

Scheme 10. 1:1 Coupling of $N$-phenylanthranilic acid with diarylacetylenes.

Under the aerobic conditions, benzoic acid also reacts not only with alkynes but also with alkenes such as acrylates smoothly (Scheme 11). ${ }^{[14]}$ In contrast to the Pd-catalyzed 1:1 coupling of these substrates, ${ }^{[4 b]}$ their 1:2 coupling involving disubstitution at both the ortho-positions of benzoic acid takes place to afford 7vinylphthalides selectively. In these cases, a rhodacycle intermediate B', generated in a similar manner to that in the reaction with alkynes (B in Scheme 5), may undergo alkene insertion and successive $\beta$-hydride elimination to form an orthomonovinylated benzoic acid. The second vinylation takes place via similar steps to lead to a 2,6-divinylated benzoic acid, which may undergo nucleophilic cyclization to yield the final product. 


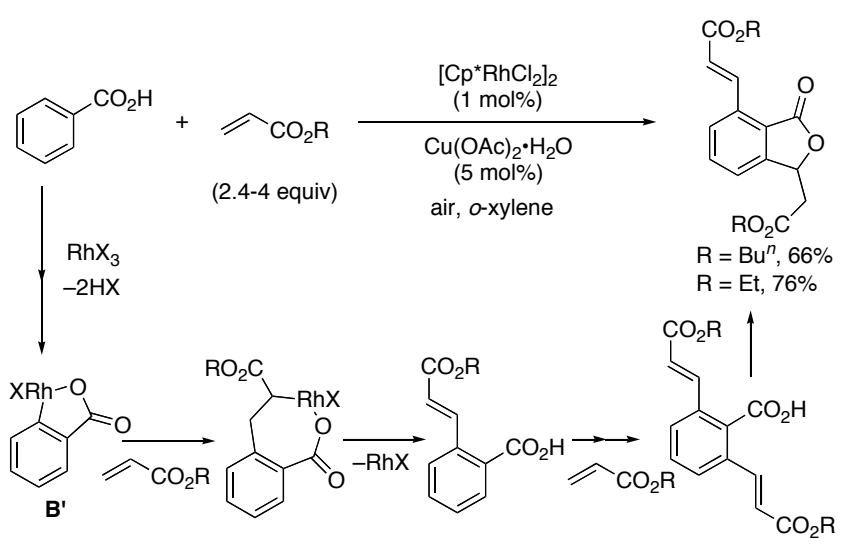

Scheme 11. 1:2 Coupling of benzoic acid with acrylates.

In contrast to the acrylates, $N, N$-dimethylacrylamide and acrylonitrile react with benzoic acid in a 1:1 manner under similar conditions (Scheme 12). In the cases with these alkenes, the cyclization exclusively occurs after the first vinylation (see Scheme 11), as occurs in the Pd-catalyzed reaction. ${ }^{[4 b]}$

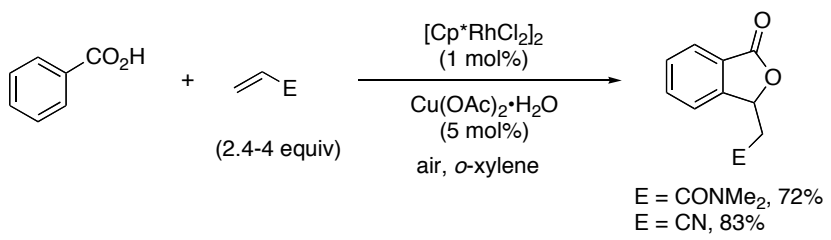

Scheme 12. 1:1 Coupling of benzoic acid with alkenes.

Under rhodium catalysis, acrylic acids also oxidatively couple with alkynes and alkenes through vinylic $\mathrm{C}-\mathrm{H}$ bond cleavage (Schemes 13 and 14). ${ }^{[17]}$ These reactions using stoichiometric amounts of $\mathrm{Ag}_{2} \mathrm{CO}_{3}$ or $\mathrm{Cu}(\mathrm{OAc})_{2} \bullet \mathrm{H}_{2} \mathrm{O}$ as oxidant give $\alpha$-pyrone and butenolide derivatives efficiently.
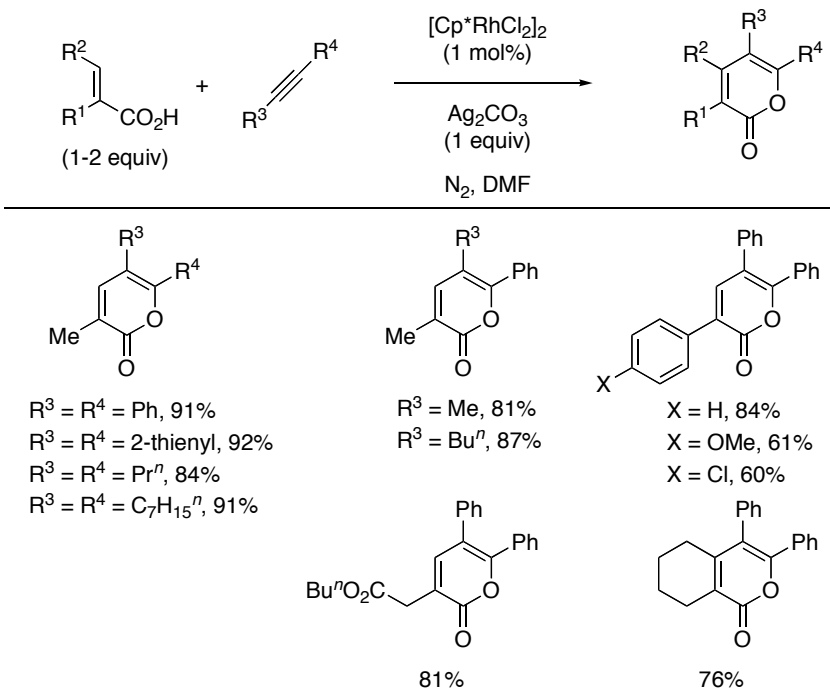

Scheme 13. 1:1 Coupling of acrylic acids with alkynes.

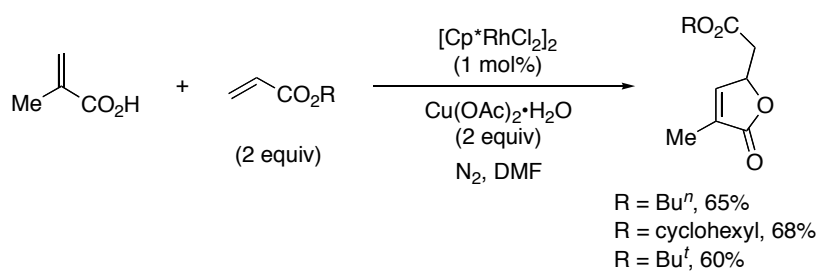

Scheme 14. 1:1 Coupling of methacrylic acid with alkenes.

\section{Coupling of Phenols and Alcohols}

It is known that salicylaldehydes, ${ }^{[18]}$ 1-naphthols, ${ }^{[19]}$ and 2phenylphenols ${ }^{[19]}$ undergo direct arylation via regioselective $\mathrm{C}-\mathrm{H}$ bond cleavage around their hydroxyl function upon treatment with aryl halides in the presence of palladium catalysts. Expectedly, under conditions using rhodium catalysts and appropriate oxidants, these substrates oxidaitvely couple with alkynes through the $\mathrm{C}-\mathrm{H}$ bond cleavage at the same positions to form fused aromatic products.

The reaction of salicylaldehydes with diarylacetylenes in the presence of $[\mathrm{RhCl}(\mathrm{cod})]_{2} / \mathrm{C}_{5} \mathrm{H}_{2} \mathrm{Ph}_{4}$ and $\mathrm{Cu}(\mathrm{OAc})_{2} \bullet \mathrm{H}_{2} \mathrm{O}$ as catalyst and oxidant, respectively, proceeds via aldehyde $\mathrm{C}-\mathrm{H}$ bond cleavage to afford 2,3-diarylchromones in good yields (Scheme $15){ }^{[20]}$
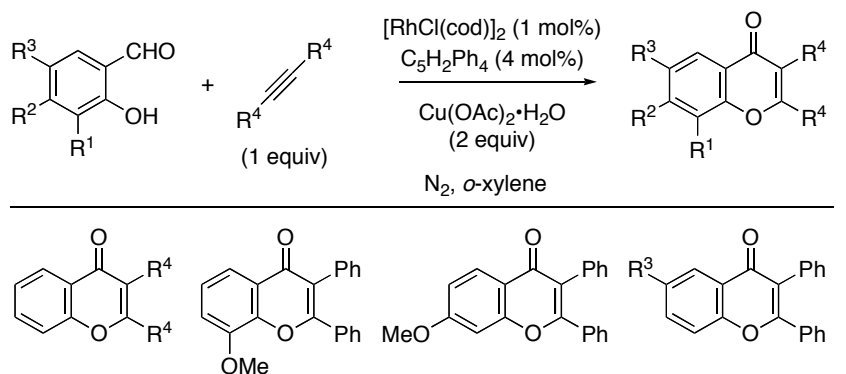

$$
\begin{array}{lll}
\mathrm{R}^{4}=\mathrm{Ph}, 92 \% & 96 \% & 90 \% \\
\mathrm{R}^{4}=4-\mathrm{MeC}_{6} \mathrm{H}_{4}, 98 \% & & \mathrm{R}^{3}=\mathrm{Cl}, 93 \% \\
\mathrm{R}^{4}=4-\mathrm{MeOC}_{6} \mathrm{H}_{4}, 92 \% & & \mathrm{R}^{3}=\mathrm{NO}_{2}, 52 \%
\end{array}
$$

$\mathrm{R}^{4}=4-\mathrm{ClC}_{6} \mathrm{H}_{4}, 83 \%$

$\mathrm{R}^{4}=2$-thienyl, $78 \%$

Scheme 15. 1:1 Coupling of salicylaldehydes with alkynes.

A plausible mechanism for the reaction of salicylaldehyde with alkynes is illustrated in Scheme 16. Coordination of the phenolic oxygen atom to an $\mathrm{Rh}^{\mathrm{III}} \mathrm{X}_{3}$ species gives an $\mathrm{Rh}^{\mathrm{III}}$ phenolate $\mathbf{E}$. Then, directed $\mathrm{C}-\mathrm{H}$ rhodation to form a rhodacycle intermediate $\mathbf{F},{ }^{[21,22]}$ alkyne insertion, and reductive elimination take place to form a chromone. The resulting $\mathrm{Rh}^{\mathrm{I}} \mathrm{X}$ species may be oxidized in the presence of a $\mathrm{Cu}^{\mathrm{II}}$ salt to regenerate $\mathrm{Rh}^{\mathrm{III}} \mathrm{X}_{3}$. While the exact role of the added $\mathrm{C}_{5} \mathrm{H}_{2} \mathrm{Ph}_{4}$ ligand is not clear, it may support the unstable $\mathrm{Rh}^{\mathrm{I}}$ species during the reoxidation step to prolong the catalyst's lifetime. 


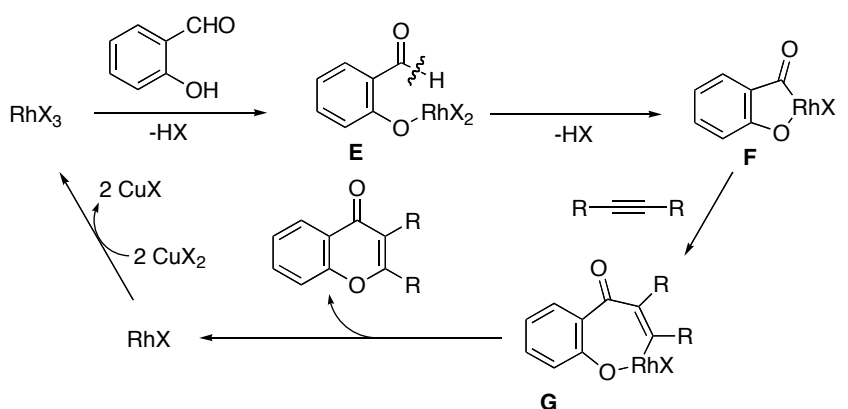

Scheme 16. A plausible mechanism for the coupling of salicylaldehyde with alkynes.

The reactions of 1-naphthols and anagolues including 4hydroxycoumarin and -quinolinone and 9-phenylxanthen-9-ol involve peri $\mathrm{C}-\mathrm{H}$ bond cleavage to produce fused pyran derivatives (Scheme 17). ${ }^{[23]}$<smiles>P#P</smiles>

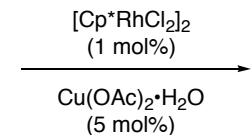
$(5 \mathrm{~mol} \%)$

air, o-xylene

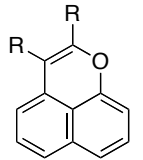

$\mathrm{R}=\mathrm{Ph}, 73 \%$ $\mathrm{R}=4-\mathrm{MeC}_{6} \mathrm{H}_{4}, 68 \%$ $\mathrm{R}=4-\mathrm{MeOC}_{6} \mathrm{H}_{4}, 74 \%$ $\mathrm{R}=4-\mathrm{ClC}_{6} \mathrm{H}_{4}, 65 \%$ $\mathrm{R}=\operatorname{Pr}^{n}, 61 \%$ $\mathrm{R}=\mathrm{C}_{7} \mathrm{H}_{15}{ }^{n}, 58 \%$<smiles></smiles>

$\mathrm{Y}=0,74 \%$ $\mathrm{Y}=\mathrm{NMe}, 96 \%$<smiles>c1ccc(-c2c3cccc2C2(O3)c3ccccc3Oc3ccccc32)cc1</smiles>
$83 \%$
$\mathrm{N}_{2}$, o-xylene<smiles>Oc1cccc2ccccc12</smiles>

(2 equiv)
Scheme 18. 1:2 Coupling of 2-phenylphenol with diphenylacetylene.

The rhodium-catalyzed oxidative coupling of triarylmethanols with alkynes proceeds through a unique pathway, which involves the successive cleavages of $\mathrm{C}-\mathrm{H}$ and $\mathrm{C}-\mathrm{C}$ bonds with elimination of diaryl ketones. ${ }^{[2]}$ The alcohols react with diarylacetylenes efficiently in the presence of $[\mathrm{RhCl}(\operatorname{cod})]_{2} / \mathrm{C}_{5} \mathrm{H}_{2} \mathrm{Ph}_{4}$ and $\mathrm{Cu}(\mathrm{OAc})_{2} \cdot \mathrm{H}_{2} \mathrm{O}$ as catalyst and oxidant, respectively, to afford 1,2,3,4-tetraarylnaphthalenes (Scheme 19).

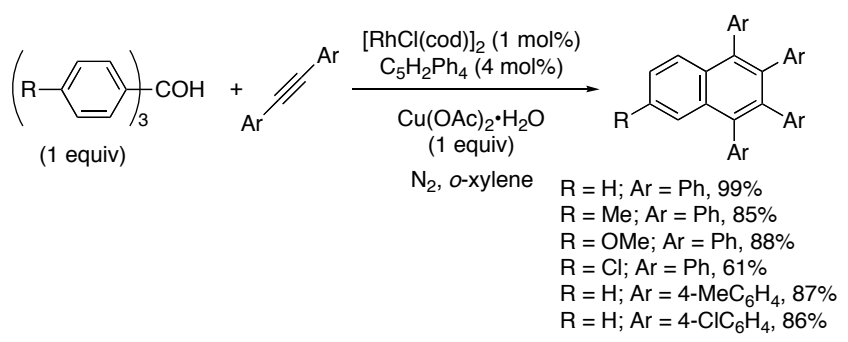

Scheme 19. 1:2 Coupling of triarylmethanols with diarylacetylenes.

Interestingly, the reaction with dialkylacethylenes can be conducted smoothly by using $\left[\mathrm{Cp} * \mathrm{RhCl}_{2}\right]_{2} / \mathrm{C}_{5} \mathrm{H}_{3} \mathrm{Ph}_{3}$ in place of $\left[\mathrm{RhCl}(\text { cod) }]_{2} / \mathrm{C}_{5} \mathrm{H}_{2} \mathrm{Ph}_{4}\right.$ (Scheme 20) $\left(\mathrm{C}_{5} \mathrm{H}_{3} \mathrm{Ph}_{3}=1,2\right.$,4-triphenyl1,3-cyclopentadiene).

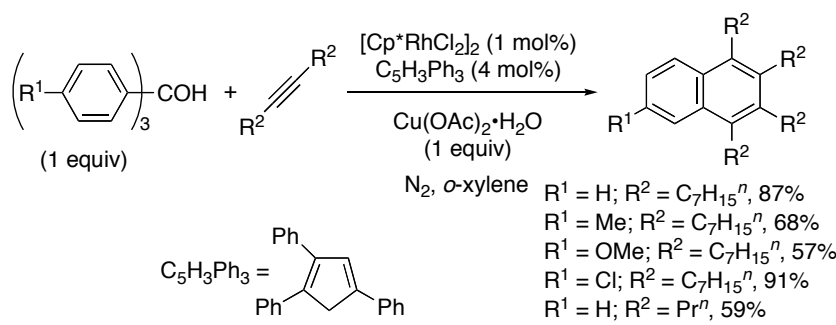

Scheme 20. 1:2 Coupling of triarylmethanols with dialkylacetylenes.

\section{Coupling of Imines} alkynes.

In contrast to such 1:1 couplings described above, 2phenylphenols reacted with alkynes in a ratio of 1:2 (Scheme 18). Thus, treatment of equal molar amounts of 2-phenylphenol, diphenylacetylene, $\mathrm{Cu}(\mathrm{OAc})_{2} \bullet \mathrm{H}_{2} \mathrm{O}$, and $\mathrm{KI}$ in the presence of $\left[\mathrm{Cp} * \mathrm{RhCl}_{2}\right]_{2}(1 \mathrm{~mol} \%)$ selectively gives 5-(2-hydroxyphenyl)$1,2,3,4$-tetraphenylnaphthalene in $81 \%$ yield.

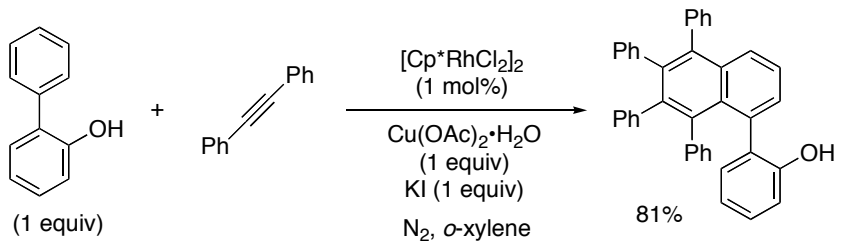



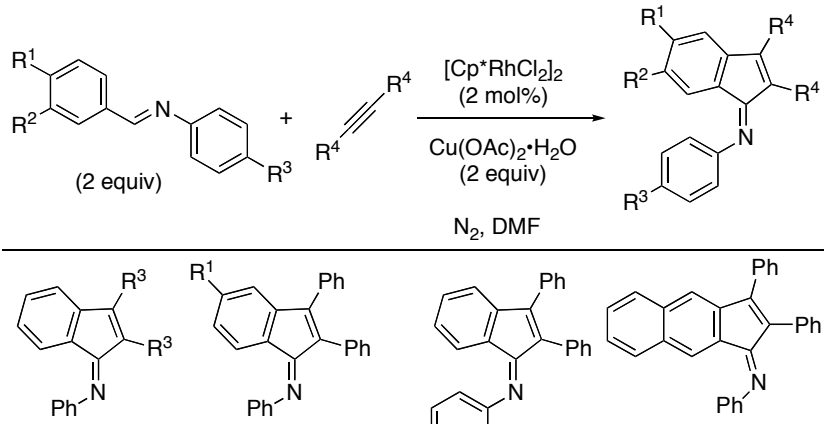

$\mathrm{R}^{3}=\mathrm{Ph}, 85 \%$ $\mathrm{R}^{1}=\mathrm{Me}, 83 \%$ $\mathrm{R}^{3}=4-\mathrm{MeC}_{6} \mathrm{H}_{4}, 68 \% \mathrm{R}^{1}=\mathrm{Cl}, 82 \%$ $\mathrm{R}^{3}=4-\mathrm{ClC}_{6} \mathrm{H}_{4}, 65 \%$ $R^{3}=\operatorname{Pr}^{n}, 40 \%$

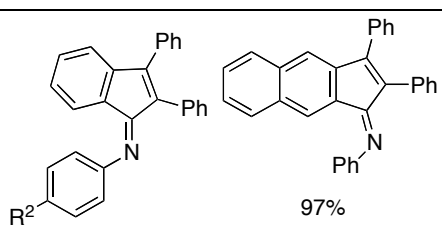

Scheme 21. 1:1 Coupling of $N$-benzylideneanilines with alkynes.

A plausible mechanism for the reaction of $N$ benzylideneaniline with alkynes is illustrated in Scheme 22. Coordination of the nitrogen atom of the imine to an $\mathrm{Rh}^{\mathrm{III}} \mathrm{X}_{3}$ species leads to the regioselective $\mathrm{C}-\mathrm{H}$ bond cleavage to afford $\mathbf{H}$. Then, alkyne insertion to form $\mathbf{I}$, intramolecular insertion of the imino moiety to form $\mathbf{J}$, and $\beta$-hydrogen elimination may successively occur to give an indenone imine. The $\mathrm{Rh}^{\mathrm{I}} \mathrm{X}$ species, formed by release of $\mathrm{HX}$, may be reoxidized by $\mathrm{Cu}^{\mathrm{II}} \mathrm{X}_{2}$.

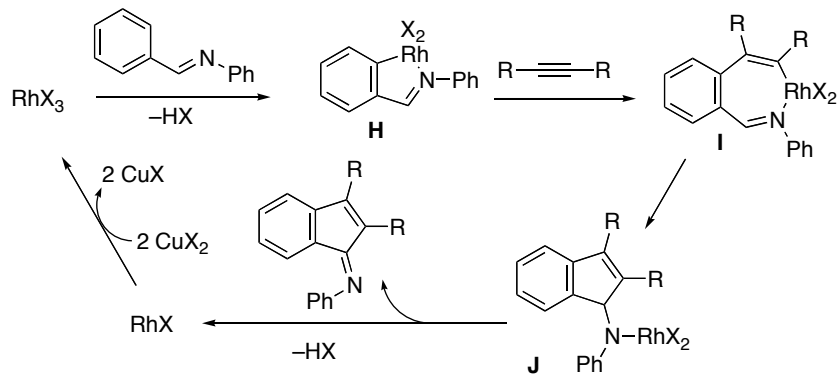

Scheme 22. A plausible mechanism for the coupling of $N$ benzylideneaniline with alkynes.

Under similar conditions, benzophenone imine efficiently undergoes the oxidative coupling with alkynes accompanied by $\mathrm{C}-\mathrm{H}$ and $\mathrm{N}-\mathrm{H}$ bond cleavages to form isoquinolines in good yields (Scheme 23).

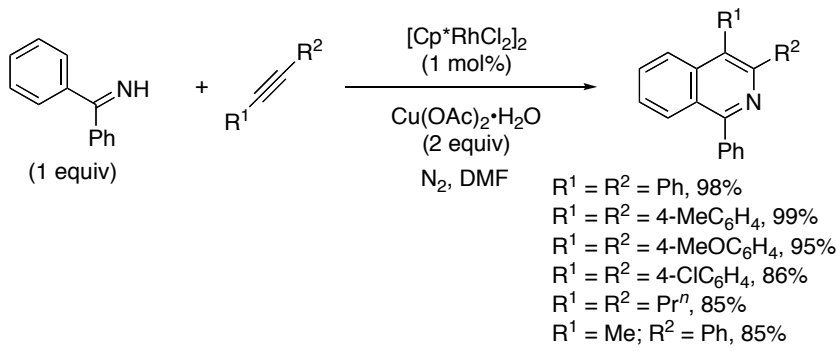

Scheme 23. 1:1 Coupling of benzophenone imine with alkynes.

As other approaches toward isoquinoline and pyridine derivatives, two step syntheses of them though the $\mathrm{Rh}^{\mathrm{I}}$-catalyzed ortho- and $\beta$-vinylation of $N$-benzylimines with alkynes and subsequent oxidative aromatization were reported by Jun's ${ }^{[27]}$ and Bergman and Ellman's groups ${ }^{[28]}$ respectively (Scheme 24).

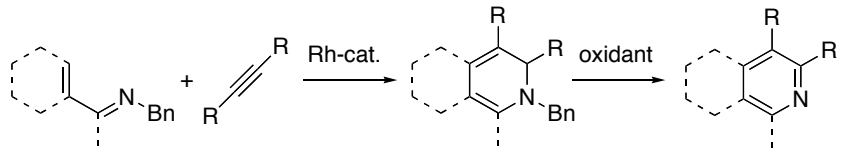

Scheme 24. 1:1 Coupling of $N$-benzylimines with alkynes.

Jones and co-workers reported the stoichiometric construction of an isoquinoline salt on a $\mathrm{Cp}^{*} \mathrm{Rh}^{\mathrm{III}}$ complex by oxidative coupling of $\mathrm{N}$-benzylidenemethylamine with dimethyl acetylenedicarboxylate (DMAD) with the aid of $\mathrm{CuCl}_{2}$ (Scheme 25). ${ }^{[29,30]}$

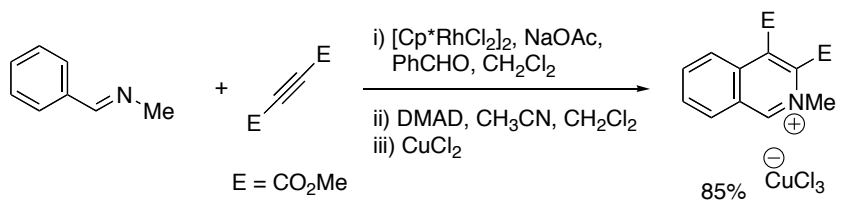

Scheme 25. 1:1 Coupling of $N$-benzylidenemethylamine with DMAD.

A single step, catalytic synthesis of isoquinolines from $\mathrm{N}$ alkylimines was achieved by Fagnou and co-workers. ${ }^{[31]}$ Thus, treatment of $\mathrm{N}$-benzylidene-tert-butylamines with alkynes (1.2 equiv) in the presence of $\left[\mathrm{Cp} * \mathrm{Rh}(\mathrm{MeCN})_{3}\right]\left[\mathrm{SbF}_{6}\right]_{2}(2.5 \mathrm{~mol} \%)$ and $\mathrm{Cu}(\mathrm{OAc})_{2} \cdot \mathrm{H}_{2} \mathrm{O}$ (2.1 equiv) in dichloroethane gives the corresponding 3,4-disubstituted isoquinolines (Scheme 26).

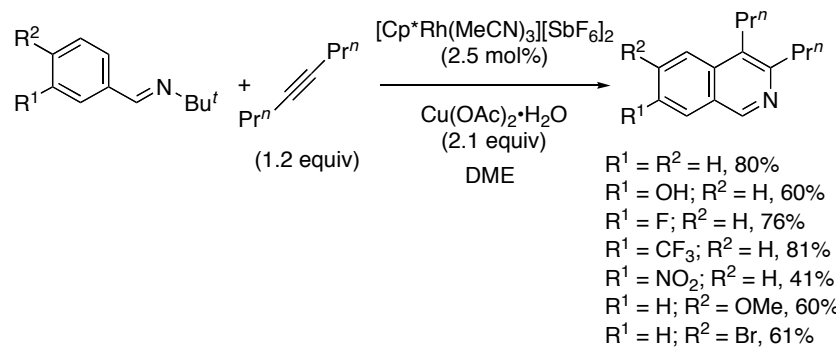

Scheme 26. 1:1 Coupling of $N$-benzylidene-tert-butylamines with alkynes.

\section{Coupling of Amides}

In 2008, Fagnou and co-workers reported that acetanilides oxidatively couple with alkynes by using a $\mathrm{Cp} * \mathrm{Rh}^{\mathrm{III}}$ catalyst and $\mathrm{Cu}(\mathrm{OAc})_{2} \cdot \mathrm{H}_{2} \mathrm{O}$ as oxidant via ortho- $\mathrm{C}-\mathrm{H}$ bond cleavage to afford $\mathrm{N}$-acetylindoles (Scheme 27, route a). ${ }^{[32]}$ Meanwhile, we found that benzanilides, which possess two kinds of cleavable ortho-C$\mathrm{H}$ bonds on anilino and benzoyl moieties, undergo the oxidative coupling with alkynes involving the selective cleavage of the latter to produce isoquinolinone derivatives (route b). ${ }^{[33]}$ 

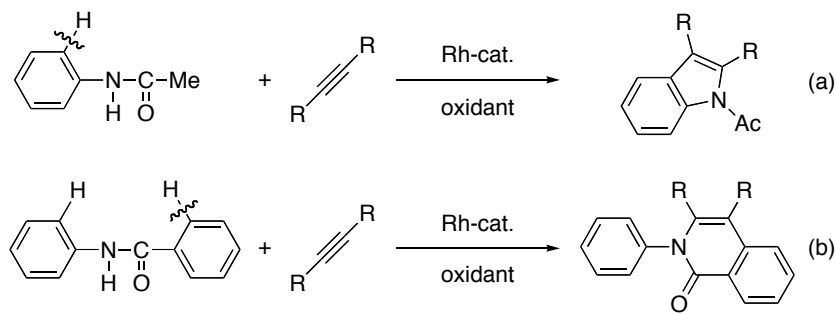

Scheme 27. 1:1 Coupling of $N$-acylanilines with alkynes.

The reaction of substituted acetanilides with 1-phenyl-1propyne (1.1 equiv) proceeds smoothly under the conditions with $\left[\mathrm{Cp}^{*} \mathrm{RhCl}_{2}\right]_{2}(2.5 \mathrm{~mol} \%), \mathrm{AgSbF}_{6}(10 \mathrm{~mol} \%)$, and $\mathrm{Cu}(\mathrm{OAc})_{2} \cdot \mathrm{H}_{2} \mathrm{O}$ (2.1 equiv) in tert-amyl alcohol, in which a similar active species to that in the reaction of $N$-benzylidene-tert-butylamines described in Scheme 26 may be generated (Scheme 28). ${ }^{[32]}$

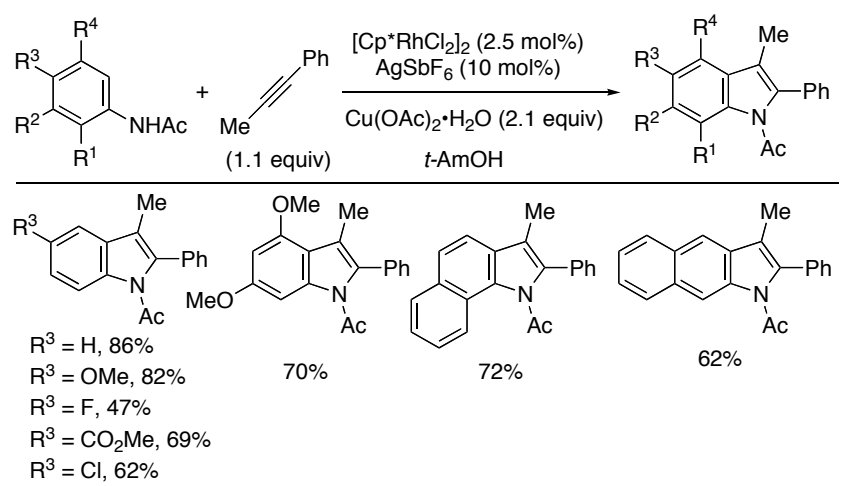

Scheme 28. 1:1 Coupling of acetanilides with 1-phenyl-1-propyne.

The reaction of $N$-monosubstituted benzamides including benzanilides with diarylacetylenes can be conducted with a more simple catalyst system without the silver salt. ${ }^{[33]}$ Thus, in the presence of $\left[\mathrm{Cp}^{*} \mathrm{RhCl}_{2}\right]_{2}(1 \mathrm{~mol} \%)$ and $\mathrm{Cu}(\mathrm{OAc})_{2} \cdot \mathrm{H}_{2} \mathrm{O}$ (2 equiv) in $o$-xylene, isoquinolinones can be obtained selectively (Scheme 29).

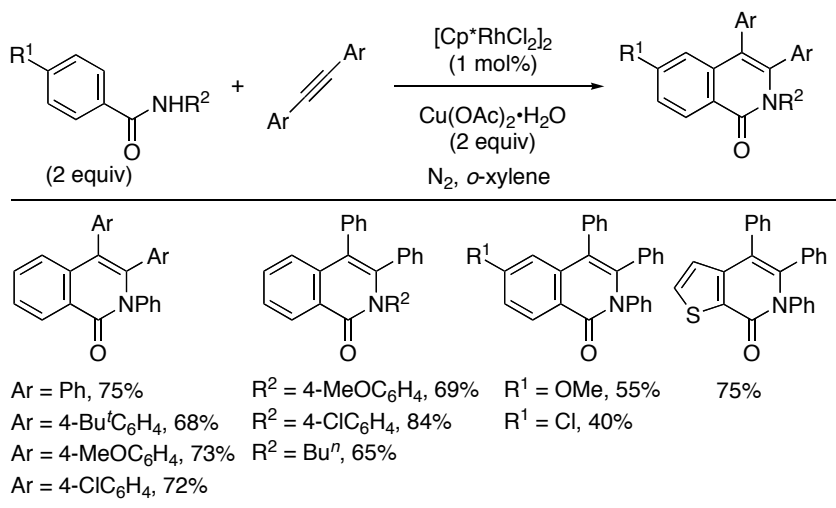

Scheme 29. 1:1 Coupling of $N$-monosubstituted benzamides with diarylacetylenes.

Under similar conditions, $N$-unsubstituted benzamides undergo 1:2 coupling accompanied by two $\mathrm{C}-\mathrm{H}$ and two $\mathrm{N}-\mathrm{H}$ bond cleavages to construct a tetracyclic dibenzoquinolizinone framework (Scheme 30).
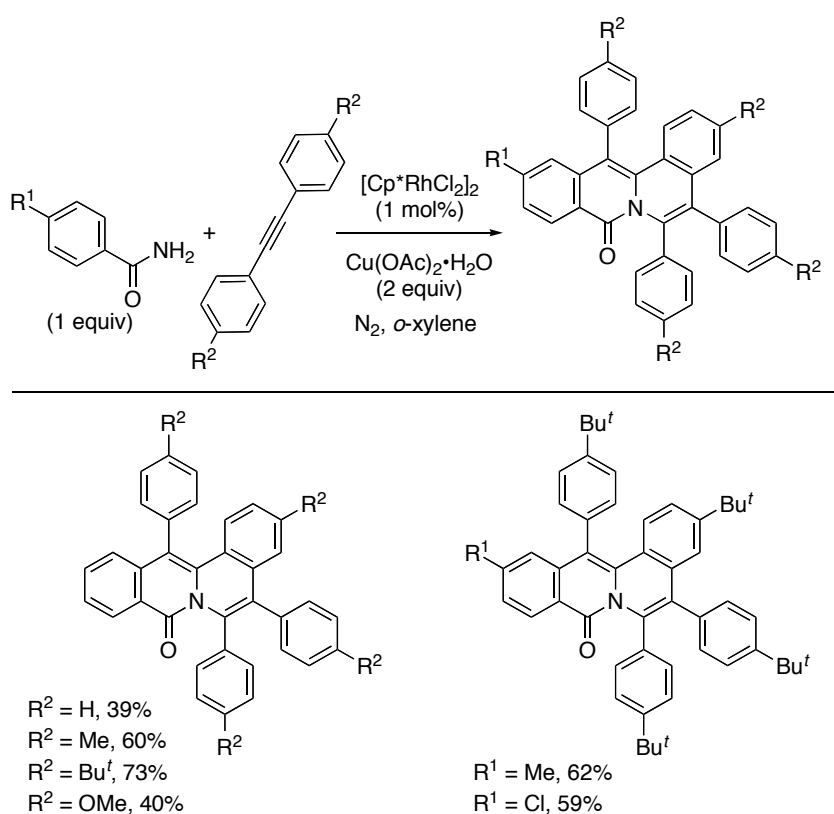

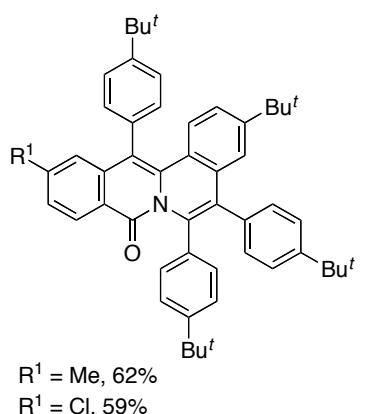

Scheme 30. 1:2 Coupling of $N$-unsubstituted benzamides with diarylacetylenes.

A plausible mechanism for the 1:2 coupling of benzamide with diphenylacetylene via directed metalation involving intermediates K-O is illustrated in Scheme 31. In the cyclorhodation steps from $\mathbf{K}$ and $\mathbf{N}$, coordination of the nitrogen atom to an $\mathrm{Rh}^{\mathrm{III}}$ species appears to be the key for the regioselective $\mathrm{C}-\mathrm{H}$ bond cleavage.

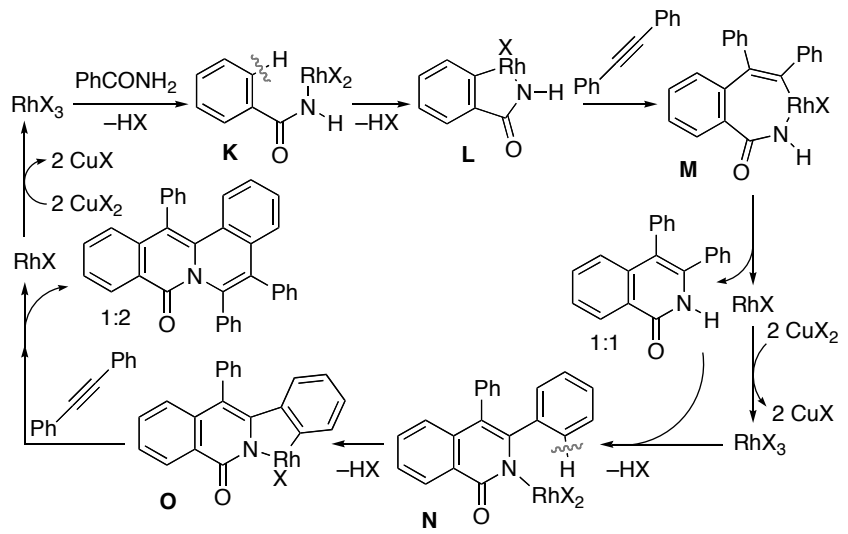

Scheme 31. A plausible mechanism for the coupling of benzamide with diphenylacetylenes.

\section{Coupling of Phenylazoles and -Pyridines}

Coordination of the nitrogen atom of phenylazoles and -pyridines toward metal center has been widely utilized for regioselective C$\mathrm{H}$ functionalization on their phenyl group. ${ }^{[1]}$ These substrates also undergo the oxidative coupling with alkynes and alkenes under rhodium catalysis as described below.

1-Phenylpyrazoles react with diarylacetylenes in the presence of $\left[\mathrm{Cp}^{*} \mathrm{RhCl}_{2}\right]_{2}(1 \mathrm{~mol} \%), \mathrm{C}_{5} \mathrm{H}_{2} \mathrm{Ph}_{4}(4 \mathrm{~mol} \%)$, and $\mathrm{Cu}(\mathrm{OAc})_{2} \bullet \mathrm{H}_{2} \mathrm{O}$ ( 1 equiv) in DMF under $\mathrm{N}_{2}$ to afford the corresponding 1-(1,2,3,4- 
tetraarylnaphthalen-5-yl)pyrazoles as 1:2 coupling products in good yields (Scheme 32 ). ${ }^{[34]}$

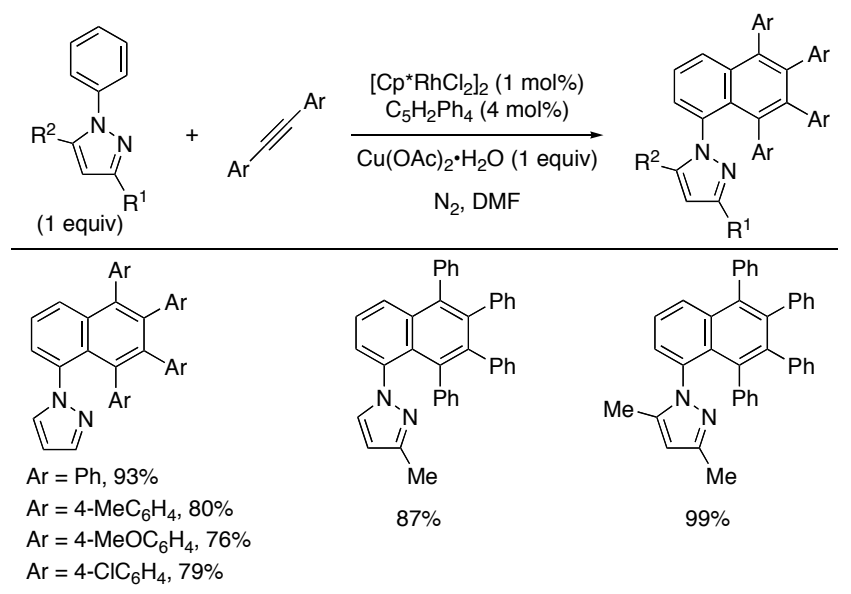

Scheme 32. 1:2 Coupling of 1-phenylpyrazoles with diarylacetylenes.

The 1:2 coupling of 1-phenylpyrazole with alkynes seems to proceed through the steps shown in Scheme 33. Coordination of the 2-N atom of 1-phenylpyrazole to an $\mathrm{Rh}^{\mathrm{III}} \mathrm{X}_{3}$ species appears to be the key for the regioselective $\mathrm{C}-\mathrm{H}$ bond cleavage to afford $\mathbf{P}$. Then, alkyne insertion into the $\mathrm{C}-\mathrm{Rh}$ bond of $\mathbf{P}$ to form $\mathbf{Q}$ and the second cyclorhodation on its phenyl ring may occur to afford $\mathbf{R}$. Subsequently, the second alkyne insertion and reductive elimination take place to produce a 1-naphthylpyrazole as a 1:2 coupling product.

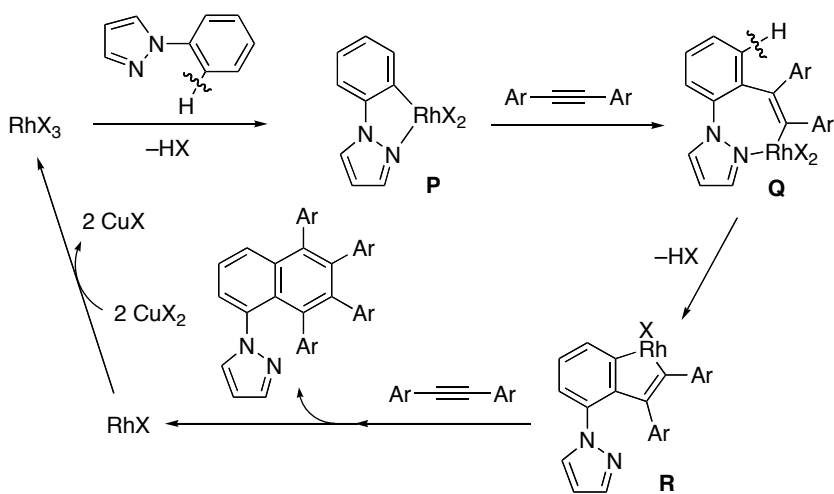

Scheme 33. A plausible mechanism for the coupling of 1phenylpyrazole with alkynes.

The stoichiometric formation of a seven-membered rhodacycle complex via similar cyclorhodation of 2phenylpyridine ${ }^{[29,35]}$ and alkyne insertion on $\mathrm{Cp}^{*} \mathrm{Rh}^{\mathrm{III}}$ species $^{[29]}$ was reported by Jones and co-workers (Scheme 34). Treatment of this complex with $\mathrm{CuCl}_{2}$ induces the oxidative coupling of the $\mathrm{C}-$ $\mathrm{N}$ bond to liberate a benzo[a]quinolizinium salt, rather than the second cyclorhodation and alkyne insertion toward the 1:2 coupling.

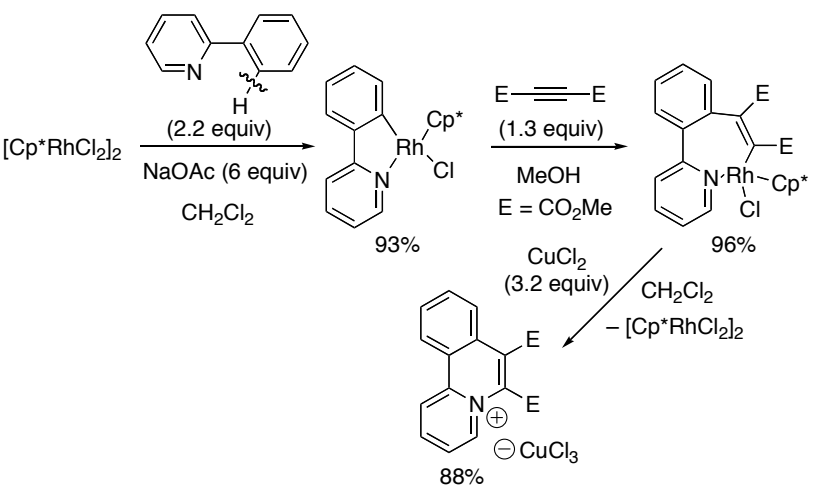

Scheme 34. 1:1 Coupling of 2-phenylpyridine with DMAD.

Similarly, the reaction of 1-methyl-2-phenyl-1Hbenzimidazole with diphenylacetylene gives a 2naphthylbenzimidazole as the 1:2 coupling product (Scheme 35). In contrast, 2-phenyl- $1 H$-benzimidazole undergoes the reaction with the alkyne in a $1: 1$ manner through $\mathrm{C}-\mathrm{H}$ and $\mathrm{N}-\mathrm{H}$ bond cleavages to selectively produce an imidazoisoquinoline. Interestingly, treatment of 2-phenylbenzoxazole with 4 equivalents of diphenylacetylene affords a 1:4 coupling product, 2-(1,2,3,4,5,6,7,8-octaphenylanthracen-9-yl)benzoxazole through the cleavage of four $\mathrm{C}-\mathrm{H}$ bonds.
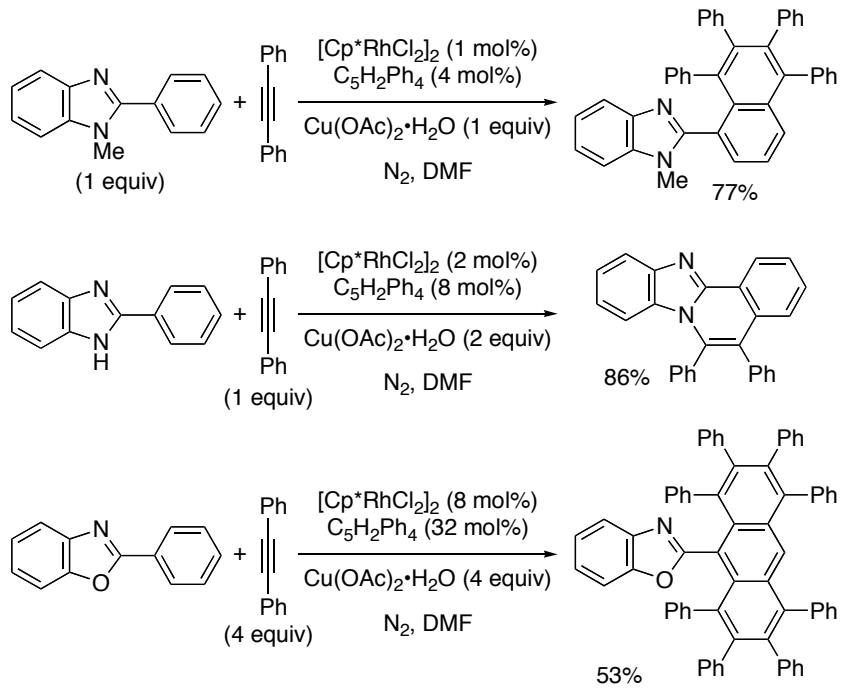

Scheme 35. Coupling of phenylazoles with diphenylacetylenes.

The oxidative coupling of 1-phenylpyrazoles with alkenes also proceeds efficiently under conditions using the $\left[\mathrm{Cp} * \mathrm{RhCl}_{2}\right]_{2} / \mathrm{Cu}(\mathrm{OAc})_{2} \cdot \mathrm{H}_{2} \mathrm{O}$ catalyst system. ${ }^{[36]}$ Depending on the ratio of substrates used, their $1: 1$ and $1: 2$ couplings selectively take place. Thus, the reaction using an excess amount of 1phenylpyrazole ( 2 equiv) with various styrenes or acrylates in the presence of $\left[\mathrm{Cp}^{*} \mathrm{RhCl}_{2}\right]_{2}(1 \mathrm{~mol} \%)$ and $\mathrm{Cu}(\mathrm{OAc})_{2} \cdot \mathrm{H}_{2} \mathrm{O}$ (2 equiv) under $\mathrm{N}_{2}$ in DMF (conditions A) affords 1-(2vinylphenyl)pyrazoles predominantly (Scheme 36). Meanwhile, the use of these substrates in a ratio of 1:2.4 (conditions B) results in the exclusive formation of 1-(2,6-divinylphenyl)pyrazoles. In the reactions with tert-butyl- and cyclohexyl acrylates the corresponding vinylated products are given as mixtures of geometrical isomers. However, treatment of the $E-Z$ mixtures with 
$\mathrm{PdCl}_{2}(\mathrm{PhCN})_{2}$ can induce isomerization around their $\mathrm{C}=\mathrm{C}$ double bonds to form thermodynamically stable $E$ - and $E, E$-isomers. ${ }^{[37]}$

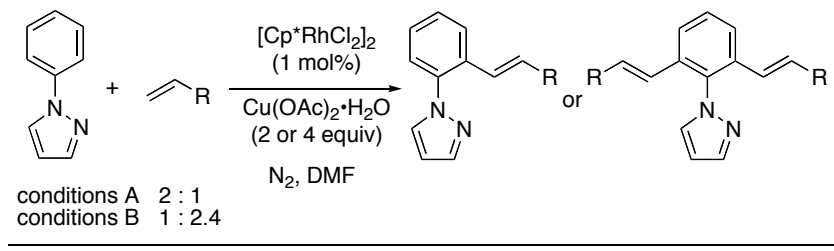

Under conditions A

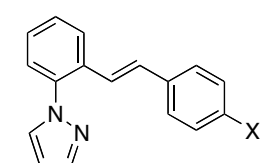

$\mathrm{X}=\mathrm{H}, 81 \%$

$\mathrm{X}=\mathrm{Me}, 79 \%$

$\mathrm{X}=\mathrm{Bu}^{t}, 80 \%$

$\mathrm{X}=\mathrm{OMe}, 81 \%$

$\mathrm{X}=\mathrm{Cl}, 74 \%$

Under conditions B<smiles>[Al]/C=C/c1cccc(/C=C/Br)c1-n1cccn1</smiles>

$\mathrm{Ar}=\mathrm{Ph}, 90 \%$

$\mathrm{Ar}=4-\mathrm{MeC}_{6} \mathrm{H}_{4}, 89 \%$

$\mathrm{Ar}=4-\mathrm{Bu}^{t} \mathrm{C}_{6} \mathrm{H}_{4}, 74 \%$

$\mathrm{Ar}=4-\mathrm{MeOC}_{6} \mathrm{H}_{4}, 64 \%$

$\mathrm{Ar}=4-\mathrm{ClC}_{6} \mathrm{H}_{4}, 68 \%$

$\mathrm{Ar}=2$-naphthyl, $80 \%\left(\right.$ with $\left.\left[\mathrm{Cp}^{*} \mathrm{RhCl}_{2}\right]_{2}(2 \mathrm{~mol} \%)\right)$

Scheme 36. Coupling of 1-phenylpyrazole with alkenes.

The mono- and divinylations of other phenylazoles and a phenylpyridine with styrene can also be conducted under conditions A and B (Scheme 37). 3-Methyl-1-phenylpyrazole and 2-phenylpyridine undergo the reaction under condtions $\mathrm{A}$ and $\mathrm{B}$ to selectively afford the corresponding mono- and divinylated products, respectively. In contrast, the divinylations of sterically more hindered 3,5-dimethyl-1-phenylpyrazole and 1-methyl-2phenylimidazole are sluggish, and monovinylated products are produced predominantly under both conditions $\mathrm{A}$ and $\mathrm{B}$.

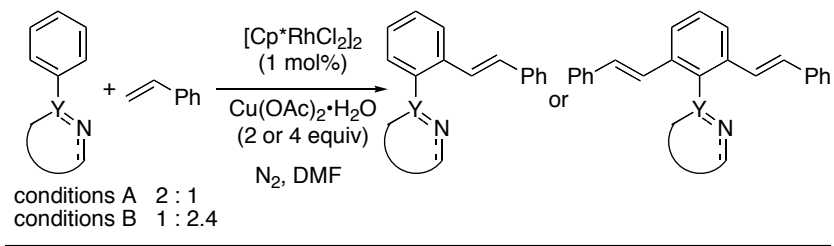

Under conditions A<smiles>Cc1ccn(-c2ccccc2/C=C/c2ccccc2)n1</smiles><smiles>Cc1cc(C)n(-c2ccccc2/C=C/c2ccccc2)n1</smiles><smiles>C(=C/c1ccccc1-c1ccccn1)\c1ccccc1</smiles>

Under conditions B<smiles>Cc1ccn(-c2c(/C=C/c3ccccc3)cccc2/C=C/c2ccccc2)n1</smiles><smiles>C(=C/c1cccc(/C=C/c2ccccc2)c1-c1ccccc1)\c1ccccc1</smiles><smiles>Cn1ccnc1-c1ccccc1/C=C/c1ccccc1</smiles>

Scheme 37. Coupling of phenylazoles and -pyridine with styrene.

\section{Summary and Outlook}

The rhodium-catalyzed oxidative coupling reactions of aromatic substrates bearing oxygen- and nitrogen-containing substitutents with alkynes and alkenes via regioselective $\mathrm{C}-\mathrm{H}$ bond cleavage have been developed significantly in recent years. ${ }^{[38]}$ These new reactions provide useful methods in preparing a variety of $\pi$ conjugated molecules from the simple, readily available substrates. Further effort will be made continuously to extend the scope of starting materials for this catalysis.

[1] For selected reviews concerning $\mathrm{C}-\mathrm{H}$ bond functionalization, see: a) D. A. Colby, R. G. Bergman, J. A. Ellman, Chem. Rev. 2010, 110, 624; b) C.-L. Sun, B.-J. Li, Z.-J. Shi, Chem. Commun. 2010, 46, 677; c) X. Chen, K. M. Engle, D.-H. Wang, J.-Q. Yu, Angew. Chem. 2009, 121, 5196; Angew. Chem., Int. Ed. 2009, 48, 5094; d) P. Thansandote, M. Lautens, Chem. Eur. J. 2009, 15, 5875; e) F. Kakiuchi, T. Kochi, Synthesis 2008, 3013; f) J. C. Lewis, R. G. Bergman, J. A. Ellman, Acc. Chem. Res. 2008, 41, 1013; g) E. M. Ferreira, H. Zhang, B. M. Stoltz, Tetrahedron 2008, 64, 5987; h) Y. J. Park, J.-W. Park, C.-H. Jun, Acc. Chem. Res. 2008, 41, 222; i) C. I. Herrerias, X. Yao, Z. Li, C.J. Li, Chem. Rev. 2007, 107, 2546; j) F. Kakiuchi, Top Organomet. Chem. 2007, 24, 1; k) L. Ackermann, Top Organomet. Chem. 2007, 24, 35; 1) T. Satoh, M. Miura, Top Organomet. Chem. 2007, 24, 61; m) D. Kalyani, M. S. Sanford, Top Organomet. Chem. 2007, 24, 85; n) D. Alberico, M. E. Scott, M Lautens, Chem. Rev. 2007, 107, 174; o) C.-H. Jun, E.-A. Jo, J.-W. Park, Eur. J. Org. Chem. 2007, 1869; p) T. Satoh, M. Miura, Chem. Lett. 2007, 36, 200; q) T. Satoh, M. Miura, J. Synth. Org. Chem. 2006, 64, 1199; r) B. L. Conley, W. J. Tenn III, K. J. H. Young, S. K. Ganesh, S. K. Meier, V. R. Ziatdinov, O. Mironov, J. Oxgaard, J. Gonzales, W. A. Goddard III, R. A. Periana, J. Mol. Catal. A 2006, 251, 8; s) F. Kakiuchi, N. Chatani, Adv. Synth. Catal. 2003, 345, 1077; t) V. Ritleng, C. Sirlin, M. Pfeffer, Chem Rev. 2002, 102, 1731; u) F. Kakiuchi, S. Murai, Acc. Chem. Res. 2002, 35, 826; v) C. Jia, T. Kitamura, Y. Fujiwara, Acc. Chem. Res. 2001, 34, 633; w) G. Dyker, Angew. Chem. 1999, 111, 1808; Angew. Chem. Int. Ed. 1999, 38, 1698; x) A. E. Shilov, G. B. Shul'pin, Chem. Rev. 1997, 97, 2879.

[2] S. Murai, .F. Kakiuchi, S. Sekne, Y. Tanaka, A. Kamatani, M. Sonoda, N. Chatani, Nature 1993, 366, 529.

[3] H. Horino, N. Inoue, J. Org. Chem. 1981, 46, 4416.

[4] a) M. Miura, T. Tsuda, T. Satoh, M. Nomura, Chem. Lett. 1997, 1103; b) M. Miura, T. Tsuda, T. Satoh, S. Pivsa-Art, M. Nomura, J. Org. Chem. 1998, 63, 5211 ; c) M. D. K. Boele, G. P. F. van Strijdonck, A. H. M. de Vries, P. C. J. Kamer, J. G. de Vries, P. W. N. M. van Leeuwen, J. Am. Chem. Soc. 2002, $124,1586$.

[5] G. Cai, Y. Fu, Y. Li, X. Wan, Z. Shi, J. Am. Chem. Soc. 2007, 129, 7666.

[6] S. H. Cho, S. J. Hwang, S. Chang, J. Am. Chem. Soc. 2008, 130, 9254

[7] S. S. Stahl, Angew. Chem. 2004, 116, 3480; Angew. Chem., Int. Ed. 2004, 43, 3400 and references therein.

[8] B. de Bruin, P. H. M. Budzelaar, A. W. Gal, Angew. Chem. 2004, 116, 4236; Angew. Chem., Int. Ed. 2004, 43, 4142.

[9] a) A. K. Fazlur-Rahman, J.-C. Tsai, K. M. Nicholas, J. Chem. Soc., Chem. Commun. 1992, 1334; b) M. Bressan, A. Morvillo, Inorg. Chim. Acta 1989, 166, 177; c) H. Mimoun, Angew. Chem. 1982, 94, 750; Angew. Chem., Int. Ed. Engl. 1982, 21, 734; d) H. Mimoun, M. M. Perez-Machirant, I. Sérée de Roch, J. Am. Chem. Soc. 1978, 100, 5437.

[10] a) T. Matsumoto, R. A. Periana, D. J. Taube, H. Yoshida, J. Catal. 2002, 206, 272; b) T. Matsumoto, H. Yoshida, Chem. Lett. 2000, 1064.

[11] For recent reviews, see: a) O. Daugulis, H.-Q. Do, D. Shabashov, Acc. Chem. Res. 2009, 42, 1074; b) L. J. Goossen, N. Rodriguez, K. Goossen, Angew. Chem. 2008, 120, 3144; Angew. Chem., Int. Ed. 2008, 47, 3100; c) O. Baudoin, Angew. Chem. 2007, 119, 1395; Angew. Chem., Int. Ed. 2007, 46, 1373.

[12] a) D.-H. Wang, K. M. Engle, B.-F. Shi, J.-Q. Yu, Science 2010, 327, 315; b) B.-F. Shi, Y.-H. Zhang, J. K. Lam, D.-H. Wang, J.-Q. Yu, J. Am. Chem. Soc. 2010, 132, 460; c) A. Maehara, H. Tsurugi, T. Satoh, M. Miura, Org. Lett. 2008, 10, 1159; d) D. Tanaka, S. P. Romeril, A. G. Myers, J. Am. Chem. Soc. 
2005, 127, 10323; e) D. Tanaka, A. G. Myers, Org. Lett. 2004, 6, 433; f) A. G. Myers, D. Tanaka, M. R. Mannion, J. Am. Chem. Soc. 2002, 124, 11250.

[13] J. M. Kisenyi, G. J. Sunley, J. A. Cabeza, A. J. Smith, H. Adams, N. J. Salt, P. M. Maitlis, J. Chem. Soc., Dalton Trans. 1987, 2459.

[14] a) K. Ueura, T. Satoh, M. Miura, J. Org. Chem. 2007, 72, 5362; b) K. Ueura, T. Satoh, M. Miura, Org. Lett. 2007, 9, 1407. For a short review, see: c) T. Satoh, K. Ueura, M. Miura, Pure Appl. Chem. 2008, 80, 1127.

[15] M. Shimizu, K. Hirano, T. Satoh, M. Miura, J. Org. Chem. 2009, 74, 3478.

[16] a) R. Rossi, A. Carpita, F. Bellina, P. Stabile, L. Mannina, Tetrahedron 2003, 59, 2067; b) K. Nozawa, M. Yamada, Y. Tsuda, K.-I. Kawai, S. Nakajima, Chem. Pharm. Bull. 1981, 29, 2689; c) S. Nakajima, K.-I. Kawai, S. Yamada, Y. Sawai, Agr. Biol. Chem. 1976, 40, 811; d) M. Okazaki, N. Yagi, Y. Wakizaka, Yuki Gosei Kagaku Kyokaishi 1968, 26, 155; e) K. Nitta, Y. Yamamoto, T. Inoue, T. Hyodo, Chem. Pharm. Bull. 1966, 14, 363.

[17] S. Mochida, K. Hirano, T. Satoh, M. Miura, J. Org. Chem. 2009, 74, 6295.

[18] T. Satoh, T. Itaya, M. Miura, M. Nomura, Chem. Lett. 1996, 823.

[19] a) Y. Kawamura, T. Satoh, M. Miura, M. Nomura, Chem. Lett. 1999, 961; b) T. Satoh, J.-I. Inoh, Y. Kawamura, Y. Kawamura, M. Miura, M. Nomura, Bull. Chem. Soc. Jpn. 1998, 71, 2239; c) T. Satoh, Y. Kawamura, M. Miura, M. Nomura, Angew. Chem. 1997, 109, 1820; Angew. Chem. Int. Ed. Engl. 1997, 36, 1740 .

[20] M. Shimizu, H. Tsurugi, T. Satoh, M. Miura, Chem. Asian J. 2008, 3, 881.

[21] For the reactions involving the cleavage of the $\mathrm{C}-\mathrm{H}$ bond on $\mathrm{Rh}^{\mathrm{I}}$, see: a) $\mathrm{K}$. Kokubo, K. Matsumasa, Y. Nishinaka, M. Miura, M. Nomura, Bull. Chem. Soc. Jpn. 1999, 72, 303; b) K. Kokubo, K. Matsumasa, M. Miura, M. Nomura, J. Org. Chem. 1997, 62, 4564; c) M. Imai, M. Tanaka, S. Nagumo, N. Kawahara, H. Suemune, J. Org. Chem. 2007, 72, 2543; d) R. T. Stemmler, C. Bolm, Adv. Synth. Catal. 2007, 349, 1185.

[22] A similar rhodacycle $\mathrm{Cp} * \mathrm{Rh}\left(\mathrm{C}(\mathrm{O}) \mathrm{C}_{6} \mathrm{~F}_{4} \mathrm{O}\right)\left(\mathrm{PMe}_{3}\right)$ has been prepared and characterized: R. P. Hughes, D. C. Lindner, L. M. Liable-Sands, A. L. Rheingold, Organometallics 2001, 20, 3519.

[23] S. Mochida, M. Shimizu, K. Hirano, T. Satoh, M. Miura, Chem. Asian J. 2010, 5,847 .

[24] T. Uto, M. Shimizu, K. Ueura, H. Tsurugi, T. Satoh, M. Miura, J. Org. Chem. 2008, 73, 298

[25] a) C.-H. Jun, C. W. Moon, D.-Y. Lee, Chem. Eur. J. 2002, 8, 2422; b) K. Ueura, T. Satoh, M. Miura, Org. Lett. 2005, 7, 2229; c) Y.-G. Lim, B. T. Koo, Tetrahedron Lett. 2005, 46, 7997; d) Y.-G. Lim, J.-S. Han, B. T. Koo, J.-B. Kang, J. Mol. Cat. A: Chemical 2004, 209, 41.

[26] T. Fukutani, N. Umeda, K. Hirano, T. Satoh, M. Miura, Chem. Commun. 2009, 5141 .

[27] S.-G. Lim, J. H. Lee, C. W. Moon, J.-B. Hong, C.-H. Jun, Org. Lett. 2003, 5, 2759.

[28] a) D. A. Colby, R. G. Bergman, J. A. Ellman, J. Am. Chem. Soc. 2008, 130, 3645 ; b) D. A. Colby, R. G. Bergman, J. A. Ellman, J. Am. Chem. Soc. 2006, 128,5604 .

[29] L. Li, W. W. Brennessel, W. D. Jones, J. Am. Chem. Soc. 2008, 130, 12414.

[30] For the cyclorhodation of imines with $\left[\mathrm{Cp} * \mathrm{RhCl}_{2}\right]_{2}$, see also: D. L. Davies, O. Al-Duaij, J. Fawcett, M. Giardiello, S. T. Hilton, D. R. Russell, Dalton Trans. 2003, 4132.

[31] N. Guimond, K. Fagnou, J. Am. Chem. Soc. 2009, 131, 12050.

[32] D. R. Stuart, M. Bertrand-Laperle, K. M. N. Burgess, K. Fagnou, J. Am. Chem. Soc. 2008, 130, 16474.

[33] S. Mochida, N. Umeda, K. Hirano, T. Satoh, M. Miura, Chem. Lett. 2010, 39, 744.

[34] N. Umeda, H. Tsurugi, T. Satoh, M. Miura, Angew. Chem. 2008, 120, 4083; Angew. Chem. Int. Ed. 2008, 47, 4019.

[35] L. Li, W. W. Brennessel, W. D. Jones, Organometallics. 2009, 28, 3492.

[36] N. Umeda, K. Hirano, T. Satoh, M. Miura, J. Org. Chem. 2009, 74, 7094.

[37] J. Yu, M. J. Gaunt, J. B. Spencer, J. Org. Chem. 2002, 67, 4627.

[38] Various kinds of $\mathrm{Rh}$-Catalyzed oxidative $\mathrm{C}-\mathrm{H}$ functionalization reactions have also been developed. Carbonylation: a) J. Zakzeski, A. Behn, M. HeadGordon, A. T. Bell, J. Am. Chem. Soc. 2009, 131, 11098; b) J. Zakzeski, S.
Burton, A. Behn, M. Head-Gordon, A. T. Bell, Phys. Chem. Chem. Phys. 2009, 11, 9903; c) V. V. Grushin, W. J. Marshall, D. L. Thorn, Adv. Synth. Catal. 2001, 343, 161. Arylation: d) T. Vogler, A. Studer, Org. Lett. 2008, 10, 129. Benzoxylation: e) Z. Ye, W. Wang, F. Luo, S. Zhang, J. Cheng, Org. Lett. 2009, 11, 3974.

Received: ((will be filled in by the editorial staff))

Revised: ((will be filled in by the editorial staff)) Published online: ((will be filled in by the editorial staff))

Scheme 1. Early examples for Pd-catalyzed oxidative coupling via regioselective C$\mathrm{H}$ bond cleavage.

Scheme 2. Rh-Catalyzed oxidative coupling of aromatic substrates with alkynes and alkenes via regioselective $\mathrm{C}-\mathrm{H}$ bond cleavage.

Scheme 3. 1:1 Coupling of benzoic acid with alkynes.

Scheme 4. 1:1 Coupling of benzoic acids with diphenylacetylene.

Scheme 5. A plausible mechanism for the coupling of benzoic acid with alkynes.

Scheme 6. 1:2 Coupling of benzoic acids with alkynes.

Scheme 7. 1:1 Coupling of heteroarene carboxylic acids with diphenylacetylene.

Scheme 8. 1:2 Coupling of aromatic diacids with 4-octyne.

Scheme 9. 1:1 Aerobic oxidative coupling of benzoic acids with diphenylacetylene.

Scheme 10. 1:1 Coupling of $N$-phenylanthranilic acid with diarylacetylenes.

Scheme 11. 1:2 Coupling of benzoic acid with acrylates.

Scheme 12. 1:1 Coupling of benzoic acid with alkenes.

Scheme 13. 1:1 Coupling of acrylic acids with alkynes.

Scheme 14. 1:1 Coupling of methacrylic acid with alkenes.

Scheme 15. 1:1 Coupling of salicylaldehydes with alkynes.

Scheme 16. A plausible mechanism for the coupling of salicylaldehyde with alkynes.

Scheme 17. 1:1 Coupling of 1-naphthols and analogues with alkynes.

Scheme 18. 1:2 Coupling of 2-phenylphenol with diphenylacetylene.

Scheme 19. 1:2 Coupling of triarylmethanols with diarylacetylenes. 
Scheme 20. 1:2 Coupling of triarylmethanols with dialkylacetylenes.

Scheme 21. 1:1 Coupling of $N$-benzylideneanilines with alkynes.

Scheme 22. A plausible mechanism for the coupling of $N$-benzylideneaniline with alkynes.

Scheme 23. 1:1 Coupling of benzophenone imine with alkynes.

Scheme 24. 1:1 Coupling of $N$-benzylimines with alkynes.

Scheme 25. 1:1 Coupling of $N$-benzylidenemethylamine with DMAD.

Scheme 26. 1:1 Coupling of $N$-benzylidene-tert-butylamines with alkynes.

Scheme 27. 1:1 Coupling of $N$-acylanilines with alkynes.

Scheme 28. 1:1 Coupling of acetanilides with 1-phenyl-1-propyne.
Scheme 29. 1:1 Coupling of $N$-monosubstituted benzamides with diarylacetylenes.

Scheme 30. 1:2 Coupling of $N$-unsubstituted benzamides with diarylacetylenes.

Scheme 31. A plausible mechanism for the coupling of benzamide with diphenylacetylenes.

Scheme 32. 1:2 Coupling of 1-phenylpyrazoles with diarylacetylenes.

Scheme 33. A plausible mechanism for the coupling of 1-phenylpyrazole with alkynes.

Scheme 34. 1:1 Coupling of 2-phenylpyridine with DMAD.

Scheme 35. Coupling of phenylazoles with diphenylacetylenes.

Scheme 36. Coupling of 1-phenylpyrazole with alkenes.

Scheme 37. Coupling of phenylazoles and -pyridine with styrene. 


\section{Text for the Table of Contents}

Rhodium catalysis: Aromatic substrates bearing oxygen- and nitrogen-containing substituents undergo oxidative coupling with alkynes and alkenes under rhodium catalysis via regioselective $\mathrm{C}-\mathrm{H}$ bond cleavage. Coordination of the substituents to the rhodium center is the key to activate the $\mathrm{C}-\mathrm{H}$ bonds effectively. Various fused-ring systems can be constructed through these reactions.

\section{Keywords}

$\mathrm{C}-\mathrm{H}$ activation $\bullet$ fused-ring systems $\bullet$ homogeneous catalysis $\bullet$ oxidative coupling $\bullet$ rhodium 